\title{
SYNTHESIS AND CHARACTERIZATION OF 6,6'-BIS (2-HYDROXYPHENYL)-2,2'-BIPYRIDYL LIGAND AND ITS PLATINUM COMPLEX FOR THE INTERACTION WITH CT-DNA
}

\author{
(Sintesis dan Pencirian Ligan 6,6'-Bis(2-Hidroksifenil)-2,2'-Bipiridil dan Kompleks Platinum \\ untuk Kajian Interaksi dengan CT-DNA)
}

\author{
Norhidayah Selamat, Lee Yook Heng, Nurul Izzaty Hassan, Nurul Huda Abd Karim* \\ School of Chemical Sciences and Food Technology, \\ Faculty of Sciences and Technology, \\ Universiti Kebangsaan Malaysia, 43600 UKM Bangi, Selangor, Malaysia \\ *Corresponding author: nurulhuda@ukm.edu.my
}

\begin{abstract}
A tetradentate ligand with four donor atoms OONN and its platinum metal complex were synthesized. Bis(phenoxy)bipyridine ligand was prepared by Suzuki coupling reaction between 6,6'-dibromo-2,2'-bipyridyl and 2-hydroxyphenylboronic acid with the presence of palladium (II) acetate. The formation of platinum complex was done by introducing the ligand with platinum (II) chloride in benzonitrile. Both ligand and complex structures were confirmed by ${ }^{1} \mathrm{H}, 2 \mathrm{D}$ cosy and ${ }^{13} \mathrm{C}$ NMR spectroscopy, ESIMS spectrometry and FTIR spectroscopy. Binding studies of small molecules with DNA are useful to understand the reaction mechanism and to provide guidance for the application and design of new and more efficient drugs or sensors targeted on DNA. In this study, the binding interaction between the synthesized ligand and complex with calf thymus DNA (CT-DNA) has been investigated using UV-Visible and emission DNA titration. From the UV-Visible DNA study, it showed that platinum (II) bipyridine complex had higher affinity towards CT-DNA with binding constant $\mathrm{K}_{\mathrm{b}}=\left(3.1 \pm 0.02 \times 10^{5}\right) \pm 0.02 \mathrm{M}^{-1}$ compared to that of bis(phenoxy) bipyridine ligand with binding constant $\left(\mathrm{K}_{\mathrm{b}}\right)=(1.19 \pm 0.08) \times 10^{3} \mathrm{M}^{-1}$. These findings will be valuable for the potential use of platinum (II) bipyridine complex as a phosphorescent probe in optical sensor DNA.
\end{abstract}

Keyword: bis(phenoxy)bipyridine, intercalating ligand, calf thymus-DNA, DNA interaction

\begin{abstract}
Abstrak
Ligan tetradentat dengan empat atom penderma OONN dan kompleks platinumnya telah disintesis. Ligan bis(fenoksi)bipiridin disediakan melalui tindak balas pengkupelan Suzuki antara 6,6'-dibromo-2,2'-bipiridil dan asid 2-hidroksifenilboronik dengan kehadiran palladium(II) asetat. Pembentukan kompleks platinum dilakukan dengan menambahkan platinum(II) klorida terhadap ligan di dalam benzonitril. Kedua-dua struktur ligan dan kompleks dibuktikan dengan spekroskopi ${ }^{1} \mathrm{H}, 2 \mathrm{D}$ dan ${ }^{13} \mathrm{C}$ RMN, spektrometri ESI-MS dan spektroskopi FTIR. Kajian pengikatan terhadap molekul kecil dengan DNA sangat berguna untuk memahami mekanisme tindak balas dan untuk panduan bagi aplikasi dan reka bentuk dadah yang baharu dan berkesan atau sensor target kepada DNA. Dalam kajian ini, interaksi ikatan antara ligan dan kompleks terhadap DNA timus anak lembu (CTDNA) dilakukan dengan kajian titratan ultra lembayung boleh Nampak dan titratan pendaflour. Kaedah tersebut membuktikan bahawa kompleks platinum (II) bipiridin mempunyai ikatan yang lebih kuat terhadap CT-DNA berbanding dengan ligan iaitu sebanyak $\mathrm{K}_{\mathrm{b}}=\left(3.1 \pm 0.02 \times 10^{5}\right) \pm 0.02 \mathrm{M}^{-1}$ berbanding $\mathrm{K}_{\mathrm{b}}=(1.19 \pm 0.08) \times 10^{3} \mathrm{M}^{-1}$. Penemuan ini sangat bernilai dan berpotensi dalam menjadikan kompleks platinum (II) bipiridin sebagai prob fosforesen dalam sensor DNA optik.
\end{abstract}

Kata kunci: bis(fenoksi)bipiridin, ligan berinterkalasi, DNA timus, interaksi DNA 


\section{Norhidayah et al: SYNTHESIS AND CHARACTERIZATION OF 6,6'-BIS(2-HYDROXYPHENYL)-2,2'- BIPYRIDYL LIGAND AND ITS PLATINUM COMPLEX FOR THE INTERACTION WITH CT-DNA}

\section{Introduction}

The mix of pyridine-phenol ligand 6,6'-(2-hydroxyphenyl)-2,2-bipyridine has attracted the author's attention due to its bridging behaviour by phenolate residues attached to the end of a string of pyridyl donors which result in the formation of phenolate-bridged polynuclear complexes with interesting magnetic and spectroscopic properties [1 3]. Interestingly, the NNOO tetradentate conjugated aromatic ligands can coordinate with metal centre results in molecular planar and increase the structural flexibility. Since deoxyribonucleic acids (DNA) offers many potential binding sites due to its size and complexity, the coordination compound are able to bind to the DNA by noncovalent bonding through three binding modes which are groove binding, intercalation and external static electronic effects [4].

Metal complex DNA intercalators have been given more attention in the research field because they are widely used in pharmaceuticals as antibiotics, antibacterial and antitumor agents [5]. Some examples of DNA interactions using transition metal complexes include $\mathrm{Ru}$ [6] $\mathrm{Co}, \mathrm{Ni}, \mathrm{Cu}, \mathrm{Zn}$ [7] and rare-earths compounds [8]. Platinum metal is chosen for the bipyridine complex in this study because it has been widely used in optical devices and has shown to have diverse applications in electroluminescence, photovoltaics, optical limiting, photocatalysis, and molecular probes [4]. Moreover, $\mathrm{d}^{8}$ square-planar platinum (II) complexes with NNOO tetradentate conjugated aromatic ligands have shown to be highly phosphorescent at room temperature and thus have the potential to be developed as DNA optical sensor for the detection of DNA hybridization [9].

To date, no attempts have been made to explore the potential of platinum (II) bipyridine complex as a new phosphorescent DNA probe. In this present work, the ligand and its platinum metal complex are synthesized and it is the interest of this study to investigate the interaction between both compound and calf thymus DNA (CT-DNA). The overall aim is to investigate their optical properties towards DNA binding. It is predicted that platinum (II) bipyridine will bind stronger to CT-DNA due to the presence of platinum metal that enables the complex to become planar, thus allows them to $\pi-\pi$ stack on the DNA bases and bind to DNA via intercalation [10]. It is expected that the bind to DNA will change the optical properties [11]. An enhancement of phosphorescence emission intensity upon the interaction with CT-DNA suggests that the platinum complex has the potential to be developed as a phosphorescence DNA sensor since there is still no report on this ligand and its complex for DNA probes sensor application [12]. Furthermore, there is a great market potential for simple, cheap, rapid, and quantitative detection of specific genes in the area of clinical, veterinary, medico-legal, environmental, and food industry.

\section{Chemicals}

\section{Materials and Methods}

The chemicals used in this work such as 6,6-dibromo-2,2'-bipyridyl, 2-methoxyphenylboronic acid, palladium (II) acetate, triphenylphospine, dimethoxyethane, pyridine hydrochloride, platinum (II) chloride and benzonitrile were purchased from Sigma-Aldrich and were used without further purification in the synthesis of ligand and complex. Calf thymus-DNA (CT-DNA) was obtained from Sigma (USA), agarose (molecular biology grade).

\section{Physical measurement}

${ }^{1} \mathrm{H}$ and ${ }^{13} \mathrm{C}$ NMR spectra of ligand were recorded using Bruker /AVANCE III $600 \mathrm{MHz}$ Fourier transform nuclear magnetic resonance $600 \mathrm{MHz}$ cryoprobe. The mass spectrometry was carried out using Bruker MicroTof Q Mass Spectrometer. IR spectra were recorded on $\mathrm{KBr}$ discs using FTIR Perkin-Elmer GX Model in the spectral range of $4000-400 \mathrm{~cm}^{-1}$. The UV-Visible spectra were measured using Shimadzu UV-2450. Melting point was measured by using Barnsted electrothermal melting point IA9100 series.

\section{Synthesis of 6,6'-bis(2-hydroxyphenyl)-2,2'-bipyridine ligand}

Bis(phenoxy)bipyridine ligand was synthesized using the method patented by Nii et al. [12] with a slight modification. 6,6'-dibromo-2,2'-bipyridine $(0.568 \mathrm{~g}, 1.81 \mathrm{mmol})$ and 2-hydroxyphenylboronic acid $(0.499 \mathrm{~g}, 3.62$ mmol) were refluxed for 4 hours in a mixture of dimethoxyethane $(10 \mathrm{~mL})$ and water $(10 \mathrm{~mL})$ with the presence of palladium (II) acetate $(0.04 \mathrm{~g}, 0.18 \mathrm{mmol})$ under inert condition. After cooling the reaction solution to room temperature, chloroform $(20 \mathrm{~mL})$ and water $(20 \mathrm{~mL})$ were added to the reaction solution. The organic layer was concentrated and collected. Purification of the organic layer was carried out by column chromatography using dicloromethane:hexane (1:2) to obtain yellow crystal of 6,6'-bis(2-hydroxyphenyl)-2,2'-bipyridyl ligand. All 
spectroscopic data for the ligand are in accordance to literature [13]. Yield : $0.3191 \mathrm{~g}(51 \%) .{ }^{1} \mathrm{H} \mathrm{NMR} \mathrm{(600} \mathrm{MHz,}$ $\left.\mathrm{CDCl}_{3}\right) \delta: 6.99\left(\mathrm{t}, 1 \mathrm{H},{ }^{3} J_{H H}=8.4 \mathrm{~Hz}\right.$, arom $), 7.09\left(\mathrm{td}, 1 \mathrm{H},{ }^{3} J_{H H}=8.4 \mathrm{~Hz}\right.$, arom $), 7.38\left(\mathrm{td}, 1 \mathrm{H},{ }^{3} J_{H H}=7.2 \mathrm{~Hz}\right.$, arom), $7.89\left(\mathrm{t}, 1 \mathrm{H},{ }^{3} J_{H H}=8.4 \mathrm{~Hz}\right.$, arom), $8.04(\mathrm{~m}, 2 \mathrm{H}$, bipyridine $), 8.14\left(\mathrm{dd}, 1 \mathrm{H},{ }^{3} J_{H H}=8.4 \mathrm{~Hz} \mathrm{H}^{2}\right), 14.29(\mathrm{~s}, 1 \mathrm{H}$, $\mathrm{OH}) .{ }^{13} \mathrm{C}$ NMR $\left(600 \mathrm{MHz}, \mathrm{CDCl}_{3}\right) \delta: 118.54,118.80,119.17,119.22,119.92,126.64,131.93,139.27,152.05$, 157.90, 159.68. IR $\left(\mathrm{cm}^{-1}\right): 3434$ (OH alcohol / phenol), 3083 (C-H aromatic), $1355(\mathrm{C}-\mathrm{N}), 1563(\mathrm{C}=\mathrm{C}$ aromatic), 1131 (C-O). ESI (+)- MS calculated for $\mathrm{C}_{22} \mathrm{H}_{16} \mathrm{~N}_{2} \mathrm{O}_{2}[\mathrm{M}+\mathrm{H}]$ : 341.12 a.m.u. Melting point : $238.5 \pm 1{ }^{0} \mathrm{C}$.

\section{Synthesis of 6,6'-bis(2-hydroxyphenyl)-2,2'-bipyridyl platinum complex}

Platinum (II) chloride (0.133 g, $0.5 \mathrm{mmol})$ was added to the 6,6'-bis(2-hydroxyphenyl)-2,2'-bipyridine ligand $(0.17$ $\mathrm{g}, 0.5 \mathrm{mmol}$ ) and heated under reflux in $10 \mathrm{~mL}$ benzonitrile for 5 hours under inert atmosphere. After cooling the reaction solution to room temperature, methanol was added to the reaction solution to yield precipitation. The reddish colour precipitate was filtered and wash using methanol and diethyl ether to obtain 6,6'-bis(2hydroxyphenyl)-2,2'-bipyridyl platinum complex. All spectroscopic data for the complex are in accordance to literature [13]. Yield : $0.0641 \mathrm{~g} \mathrm{(24 \% ).}{ }^{1} \mathrm{H}$ NMR $\left(600 \mathrm{MHz}, \mathrm{CDCl}_{3}\right) \delta: 6.78\left(\mathrm{~m}, 1 \mathrm{H},{ }^{4} J_{H H}=1.8 \mathrm{~Hz}\right.$, arom $), 7.15$ $\left(\mathrm{m}, 1 \mathrm{H},{ }^{4} J_{H H}=1.8 \mathrm{~Hz}\right.$, arom $), 7.38\left(\mathrm{~m}, 1 \mathrm{H},{ }^{4} J_{H H}=2.4 \mathrm{~Hz}\right.$, arom $), 8.24\left(\mathrm{t}, 1 \mathrm{H},{ }^{3} J_{H H}=6.3 \mathrm{~Hz}\right.$, arom $), 8.41(\mathrm{t}, 1 \mathrm{H}$, ${ }^{3} J_{H H}=12 \mathrm{~Hz}$, arom $), 8.54\left(\mathrm{~d}, 1 \mathrm{H},{ }^{3} J_{H H}=12 \mathrm{~Hz}\right.$, arom $)$ and $8.64\left(\mathrm{t}, 1 \mathrm{H},,{ }^{3} J_{H H}=12.6 \mathrm{~Hz}\right.$, arom $) .{ }^{13} \mathrm{C}$ NMR $(600$ $\left.\mathrm{MHz}, \mathrm{CDCl}_{3}\right) \delta: 116.65,120.64,121.15,122.64,124.55,129.54,131.84,137,149.28,155.54,162.16$. IR (cm-1): $3089\left(\mathrm{C}-\mathrm{H}\right.$ aromatic), $1603(\mathrm{C}-\mathrm{N}), 1346\left(\mathrm{C}=\mathrm{C}\right.$ aromatic), $1130(\mathrm{C}-\mathrm{O})$. ESI(+)- MS calculated for $\mathrm{C}_{22} \mathrm{H}_{16} \mathrm{~N}_{2} \mathrm{O}_{2}$ $[\mathrm{M}+\mathrm{H}]: 533.34$ a.m.u.

\section{DNA binding experiments: UV-Vis titration study}

A calf-thymus (CT) DNA was dissolved in a $10 \mathrm{mM}$ Tris- $\mathrm{HCl} / 100 \mathrm{mM} \mathrm{KCl} \mathrm{(pH7.4)} \mathrm{buffered} \mathrm{overnight.} \mathrm{The} \mathrm{test}$ compound was dissolved in a mixture of DMSO to give $5 \mathrm{mM}$ stock solution. For working solution, the stock solution was diluted to $1 \mathrm{mM}$ using DMSO and further diluted using the buffer to give appropriate concentrations [11]. A $1 \mathrm{~cm}$ pathlength quartz cuvette was used to conduct the measurements. The concentration of DNA used for the binding experiments was determined by measuring the absorption intensity at $260 \mathrm{~nm}$ with a molar extinction coefficient value of $6600 \mathrm{M}^{-1} \mathrm{~cm}^{-1}$ [14]. The absorption titration experiments were performed by keeping the concentration of the ligand constant $(20 \mu \mathrm{M})$ while varying the DNA concentrations $\left(4.68 \times 10^{-5} \mathrm{M}\right.$ to $\left.1.26 \times 10^{-3} \mathrm{M}\right)$. Absorbance values were recorded after each successive addition of DNA solution and equilibration (Figure 5). The percentage of hypochromicity was calculated according to Equation (1):

$$
\% \text { hypochromicity }=[(\varepsilon \text { free }-\varepsilon \text { bound }) / \varepsilon \text { free }] \times 100=16.04 \%
$$

The intrinsic binding constant $\left(\mathrm{K}_{\mathrm{b}}\right)$ of ligand - DNA was determined according to Equation (2):

$$
\frac{D N A}{\Delta z a p}=\frac{D N A}{\Delta z}+\frac{1}{\Delta z \times K}
$$

where the apparent molar extinction coefficient, $\Delta \varepsilon a p=|\varepsilon \mathrm{A}-\varepsilon \mathrm{F}|, \varepsilon \mathrm{A}=\mathrm{A}$ observed /[ligand],$\quad \Delta \varepsilon=|\varepsilon \mathrm{B}-\varepsilon \mathrm{F}|$. The $\varepsilon \mathrm{F}$ and $\varepsilon \mathrm{B}$ represent the molar extinction coefficients for free ligand and DNA bound platinum ligand respectively. From the plotted graph of [DNA] ( $\Delta \varepsilon a p)$ versus [DNA], the y-intercept is equal to $1 /(\Delta \varepsilon a p \times \mathrm{K})$, whereas the slope is equal to $1 / \Delta \varepsilon a p$. $K$ is obtained by dividing the slope value by the y-intercept [15]. Excitation wavelengths of 328 $\mathrm{nm}$ and $485 \mathrm{~nm}$ were used for DNA emission studies.

\section{Emission study}

Platinum (II) complex was dissolved in DMSO to yield $5 \mathrm{mM}$ stock solutions. Prior to use, the compounds were diluted to $1 \mathrm{mM}$ using DMSO. This was then further diluted using $10 \mathrm{mM}$ Tris $-\mathrm{HCl}(\mathrm{pH}$ 7.4) to appropriate concentrations. Aliquots of millimolar stock solution of DNA in Tris- $\mathrm{HCl}$ buffer $(49 \mu \mathrm{M})$ were added to the solutions of the test complex $(49 \mu \mathrm{M})$. The emission spectra were recorded at $\lambda=400-700 \mathrm{~nm}$ after $1 \mathrm{~min}$ equilibration and the luminescence enhancement at $\lambda_{\max }=328 \mathrm{~nm}$ and $485 \mathrm{~nm}$ were determined. 


\section{Norhidayah et al: SYNTHESIS AND CHARACTERIZATION OF 6,6'-BIS(2-HYDROXYPHENYL)-2,2'- BIPYRIDYL LIGAND AND ITS PLATINUM COMPLEX FOR THE INTERACTION WITH CT-DNA}

\section{Results and Discussion}

\section{Synthesis of 6,6'-bis(2-hydroxyphenyl)-2,2'-bipyridine ligand and its platinum complex}

The 6,6'-bis(2-hydroxyphenyl)-2,2'-bipyridine ligand was successfully prepared via Suzuki coupling reaction using the starting material 2-hydroxyphenylboronic acid. The formation of the ligand was confirmed by spectroscopic and analytical methods. Platinum (II) chloride was introduced to the 6,6'-bis(2-hydroxyphenyl)-2,2'-bipyridine ligand and heated under reflux in $10 \mathrm{~mL}$ benzonitrile for 5 hours under inert atmosphere. The reaction scheme is shown in Figure 1. The formation of the platinum (II) complex was also confirmed by spectroscopic and analytical methods.

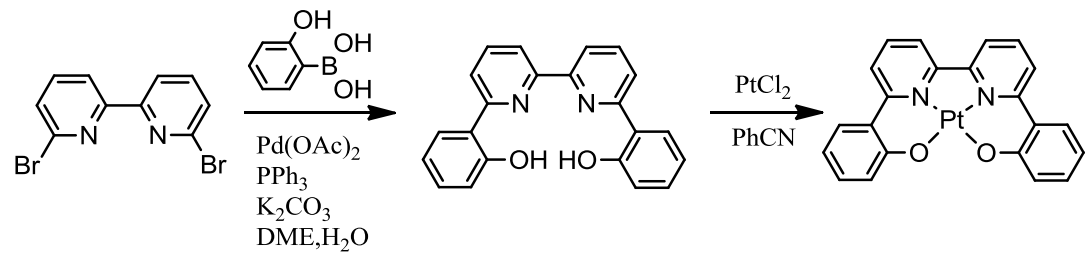

Figure 1. Synthesis of 6,6'-bis(2-hydroxyphenyl)-2,2'-bipyridine ligand via Suzuki coupling reaction and its coordination with metal

Figure 2 shows the NMR spectrum of 6,6'-bis(2-hydroxyphenyl)-2,2'-bipyridine ligand while Figure 3 shows the NMR spectrum of its platinum complex. The resonance at area $14.28 \mathrm{ppm}$ from the spectrum of the ligand is assigned to the $\mathrm{OH}$ proton which is highly deshielded due to the large anisotropic field that is generated by the circulation of $\pi$ electron in the aromatic ring. The disappearance of the resonance in the complex spectrum confirms that the deprotonation of $\mathrm{OH}$ groups occurred due to the coordination of oxygen atoms to the platinum (II) metal ion centre. The peaks at area 6.97 to $8.15 \mathrm{ppm}$ in the ligand spectrum are assigned to the aromatic ring proton which is slightly shifted upfield compared to the corresponding peaks in the complex spectrum due to the presence of more electrons withdrawing $\mathrm{OH}$ group, and thus increases the shielding of the hydrogen, causing them to move upfield.

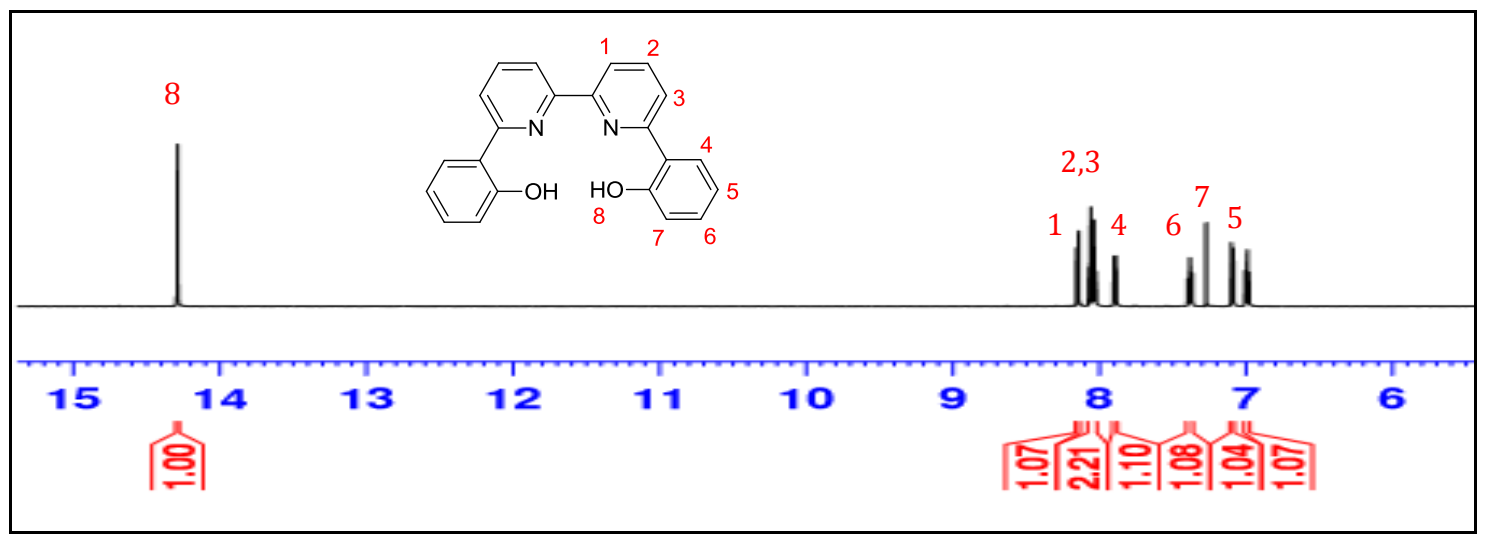

Figure 2. NMR spectrum of 6,6'-bis(2-hydroxyphenyl)-2,2'-bipyridine ligand 


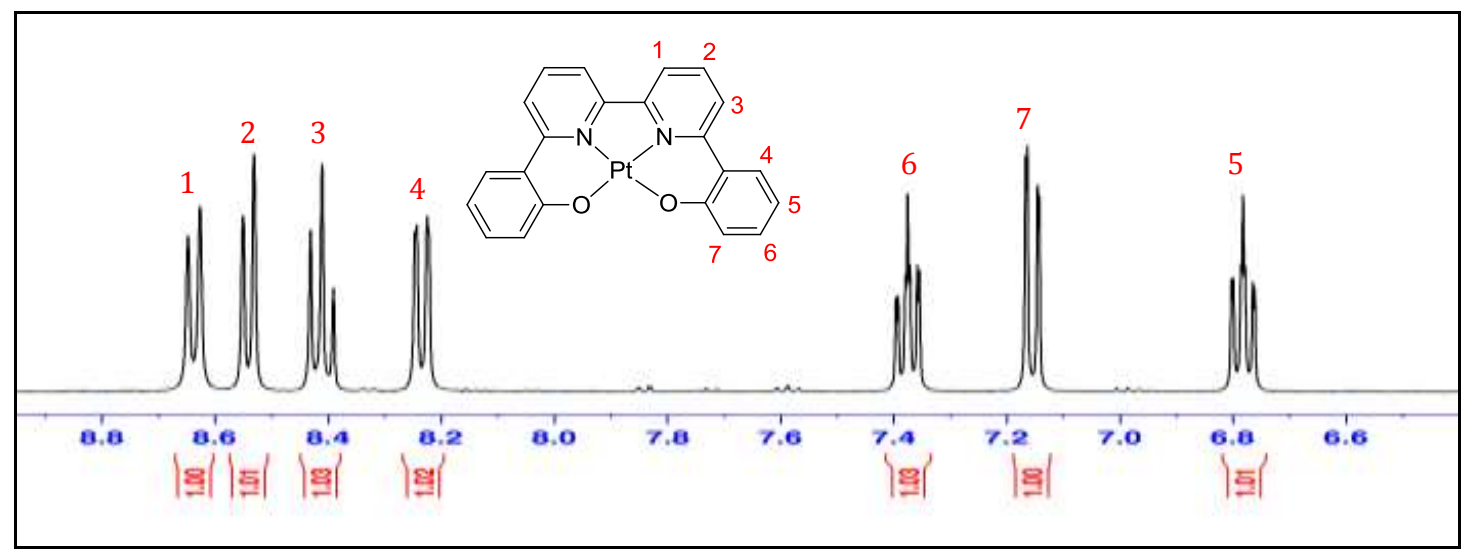

Figure 3. NMR spectrum of platinum (II) bipyridine complex

The assignment of both ${ }^{1} \mathrm{H}$ NMR spectra in $\mathrm{CHCl}_{3}$ was also performed with the help of $2 \mathrm{D}-{ }^{1} \mathrm{H}-{ }^{1} \mathrm{H}$ NMR spectroscopy. The peaks around $7.04-8.5 \mathrm{ppm}$ are assigned accordingly to the 2D-COSY NMR as shown in Figure 4(a) and Figure 4(b). The structure obtained was also confirmed by the ${ }^{13} \mathrm{C}$ NMR that shown on Figure 5(a) and Figure 5(b). From the spectrum, it is clearly shown that there was 11 signal peak that represented the presence of 11 carbon in the both structure, ligand and complex.

The infrared spectrum of the complex in Figure 6 represented the absorption band of azomethine $-\mathrm{CH}=\mathrm{N}-, \mathrm{C}-\mathrm{O}$, $\mathrm{C}=\mathrm{C}$ aromatic and $\mathrm{C}-\mathrm{H}$ aromatic at $1603 \mathrm{~cm}^{-1}, 1346 \mathrm{~cm}^{-1}$ and $3089 \mathrm{~cm}^{-1}$ respectively. The disappearance of hydrogen bonded $\mathrm{OH}$ absorption band at $3400 \mathrm{~cm}^{-1}$ in the complex spectrum supports the coordination of four donor atom $\mathrm{N}_{2} \mathrm{O}_{2}$ from ligand to platinum (II) metal ion centre, indicating a square planar geometry and aromatic rings structure. The formation of the ligand and complex was also supported by the mass spectrometry results in which the mass to charge ratio was $[\mathrm{M}+\mathrm{H}] 341.12$ a.m.u for the ligand and $[\mathrm{M}+\mathrm{H}] 534.4$ a.m.u for the complex. The melting point recorded for this ligand was $238.5 \pm 1{ }^{\circ} \mathrm{C}$.

(a)

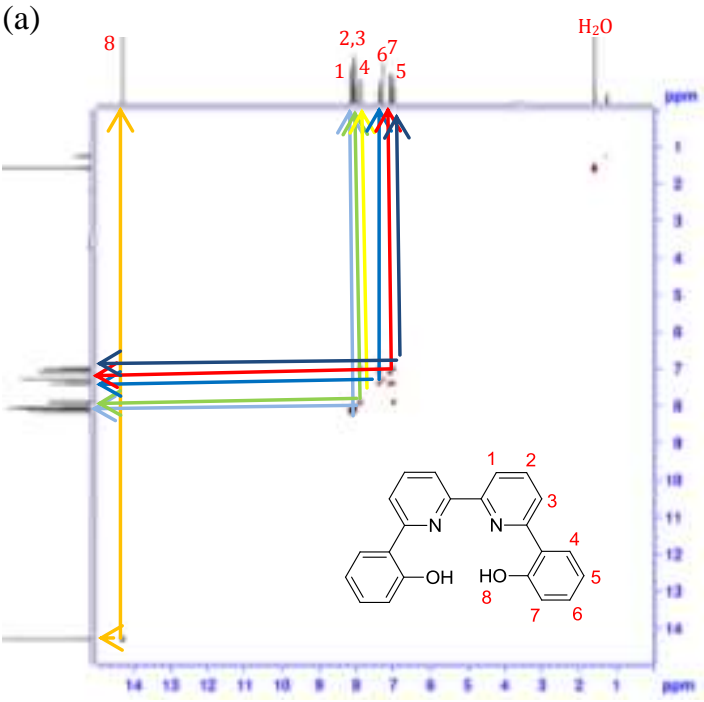

(b)

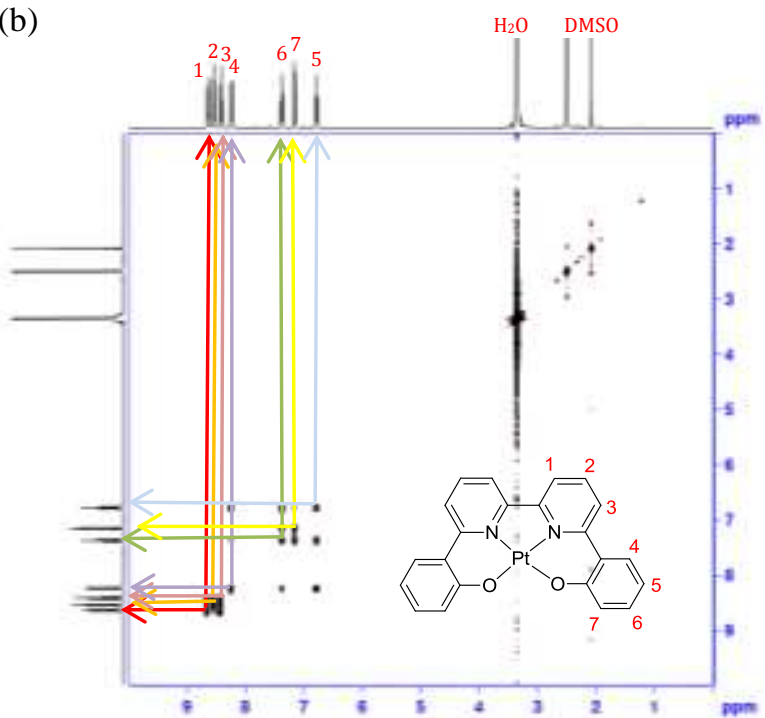

Figure 4. (a) 2D-COSY NMR of the ligand (b) 2D-COSY NMR of the complex 
(a)

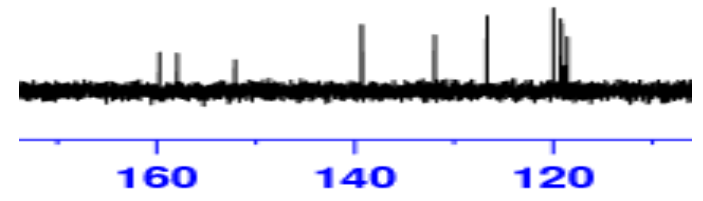

(b)

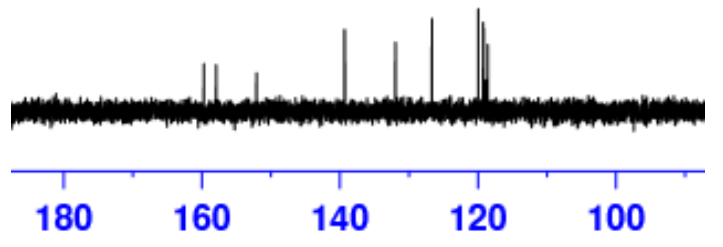

Figure 5. (a) ${ }^{13} \mathrm{C}$ NMR of the ligand (b) ${ }^{13} \mathrm{CNMR}$ of the complex

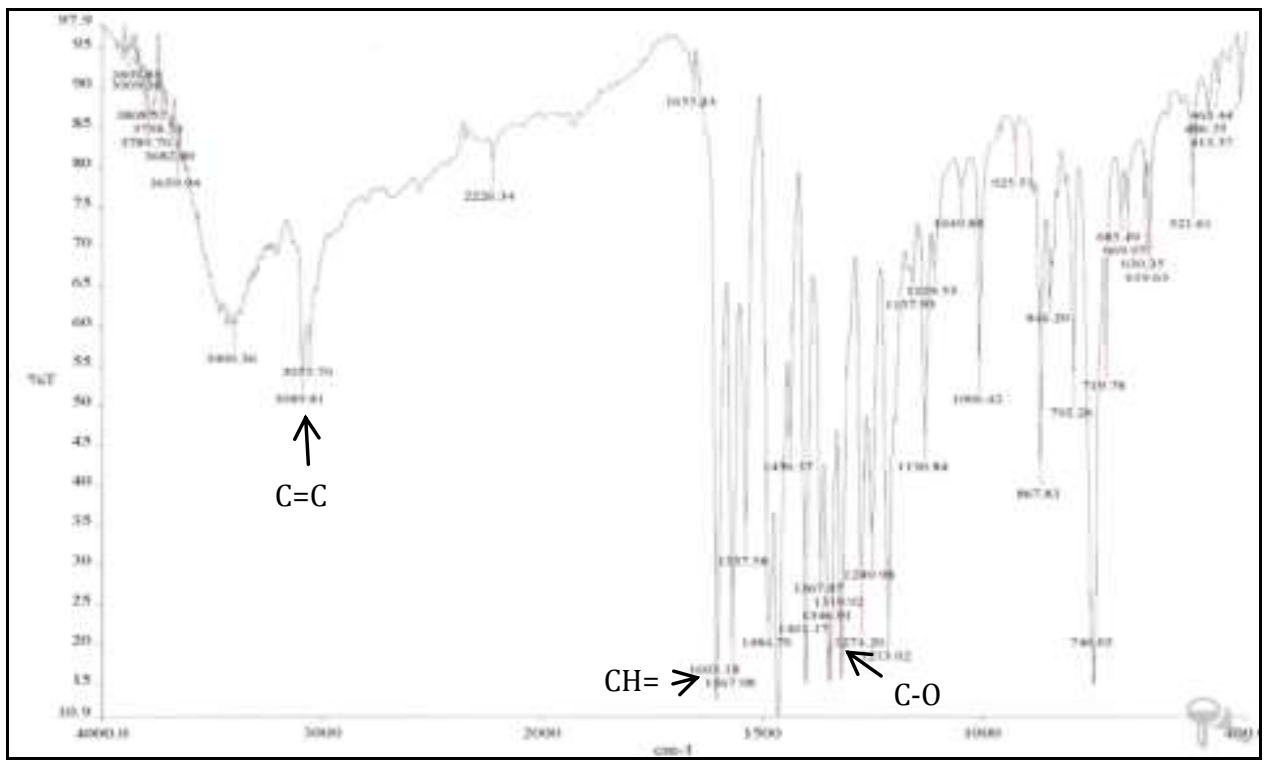

Figure 6. Infrared spectrum of the complex

\section{UV-Vis DNA titration}

The application of electronic absorption spectroscopy is one of the most useful techniques in DNA-binding studies. Since no DNA-binding studies have been reported yet on this ligand and its complex, the UV-Vis study was conducted to examine any susceptible interaction between both compound and CT-DNA, and also to study the comparison of the binding affinity between free ligand and with the presence of platinum metal centre ion. Generally, ligands that are coordinated to a metal centre result in a molecule planar and could increase its ability to intercalate between the DNA bases of double helix [15]. Therefore, the presence of metal ion will proposed the square planar geometry and thus will strongly bind to CT-DNA, presumably via intercalation mechanism compared to free ligand. The binding of intercalative compounds to DNA can be characterized by absorption spectral titrations, where lowering in absorbance (hypochromism) and shift to longer wavelengths (red shift) were observed [11]. Hypochromic effect is the spectral features of DNA concerning its interaction between the 
electronic states of the compound and DNA base while red shift occurs due to the decrease in energy gap between HOMO and LUMO molecular orbitals after binding the complex to DNA [16].

The UV-Vis absorption spectra of the platinum complex showed three intense bands at $328 \mathrm{~nm}, 485 \mathrm{~nm}$ and $528 \mathrm{~nm}$ (Figure 7(a)). UV-Vis absorption spectra of the complex in Figure 7(a) demonstrated that the addition of increasing amounts of CT-DNA resulted in $16 \%$ hypochromism at $528 \mathrm{~nm}$ and a slight red shift $(3 \mathrm{~nm})$. The hypochromism value was less compared to the absorption spectra of the ligand (Figure 8) which gave $46 \%$ hypochromicity upon the addition of increasing amounts of CT-DNA at $341 \mathrm{~nm}$ with the same red shift $(3 \mathrm{~nm})$. These results showed that there was an interaction between the electronic states of the chromophores in the both ligand and complex conjugates with DNA [5]. However, the intrinsic binding constant value $\left(\mathrm{K}_{\mathrm{b}}\right)$ of the ligand was found to be $(1.19 \pm 0.08) \times 10^{3} \mathrm{M}^{-1}$ which was 260 -folds less the metal complex whose binding constant is $(3.1 \pm$ $0.02) \times 10^{5} \mathrm{M}^{-1}$. This means that the complex binds better than the ligand due to its planar aromatic rings structure. Square planar geometry can make the molecule planar, hence increases its intercalation properties [14].

The observed spectroscopic characteristics suggest that the complex interacts with CT-DNA through a mode that involves $\pi-\pi$ stacking interaction between the aromatic rings of ligand and the base pairs of CT-DNA while the ligand bind to CT-DNA via outside binding mode interaction such as electrostatic [17] . Our results support the theory by Liu and Sadler [10], which stated that the square-planar platinum(II) complexes containing heterocyclic aromatic ligands bind to DNA duplexes non-covalently by intercalating between the base pairs. Besides, it is in good agreement with the data for other well-known intercalator metal complexes: hypochromicity values $(15-30 \%)$, red shift $(3-5 \mathrm{~nm})$ and binding constants $5.20 \times 10^{4} \mathrm{M}^{-1}$ and $8.60 \times 10^{4} \mathrm{M}^{-1}$ for 3 -ethylpiperidineoxy-2-[(2-(piperidin-1-yl)ethoxy)phenyl]-pyridine)-2(N,O)-(5-nitro-8-quinolinolato) platinum (II) and $\quad N, N^{\prime}$-bis[4-[[1-(2-ethyl)piperidine]oxy]salicylidene]-4-(2-(piperidin-1-yl)ethoxy)-1,2-phenylenediamineplatinum(II), respectively [11].

(a)

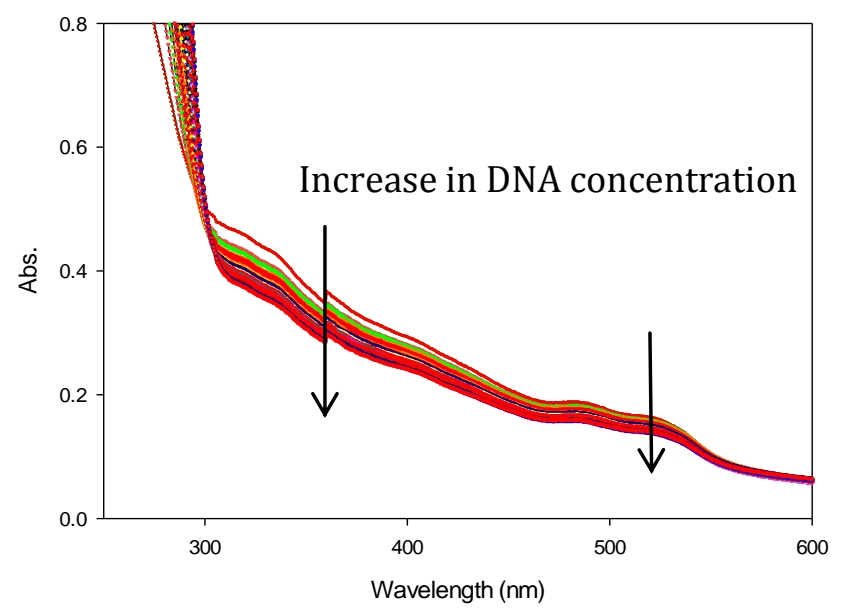

(b)

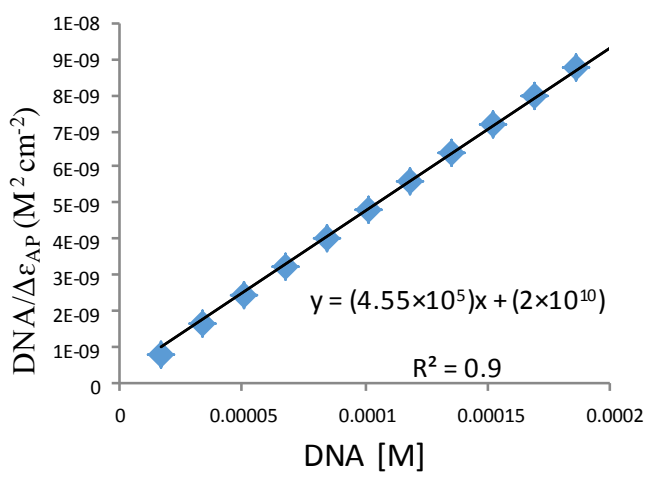

Figure 7. (a) Absorption spectral changes of complex $(30 \mu \mathrm{M})$ in TRIS.HCl buffer $(\mathrm{pH}=7.4)$ in absence and presence of increasing concentration of CT-DNA $\left(4.68 \times 10^{-5} \mathrm{M}\right.$ to $\left.1.26 \times 10^{-3} \mathrm{M}\right)$ (b) the reciprocal plot that fits the absorbance data to obtain the binding constant. 
(a)

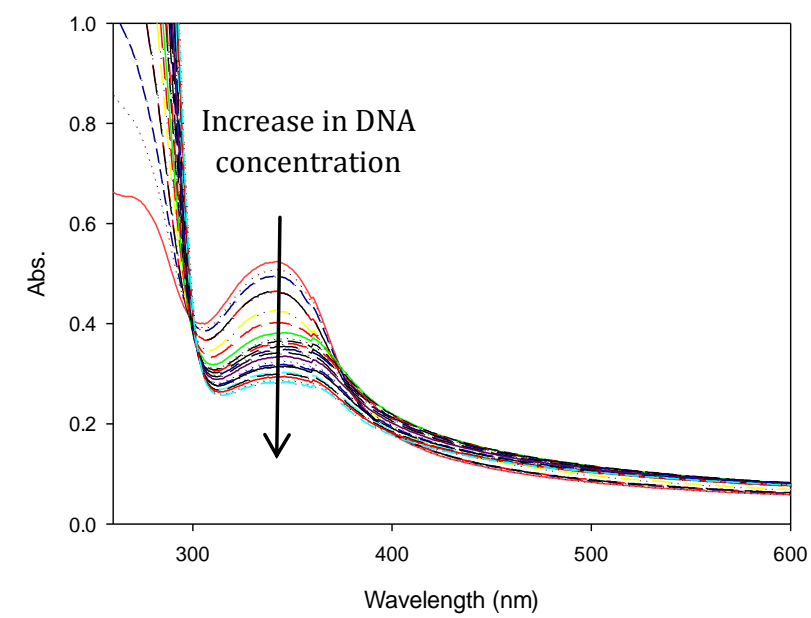

(b)

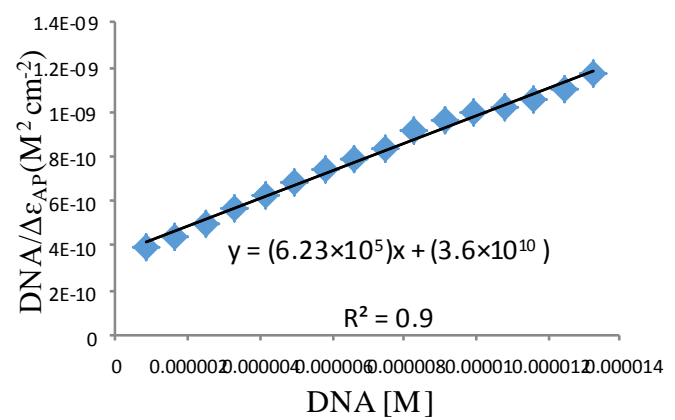

Figure 8. (a) Absorption spectral changes of ligand $(30 \mu \mathrm{M})$ in TRIS.HCl buffer $(\mathrm{pH}=7.4)$ in absence and presence of increasing concentration of CT-DNA $\left(4.68 \times 10^{-5} \mathrm{M}\right.$ to $\left.1.26 \times 10^{-3} \mathrm{M}\right)$. (b) The reciprocal plot that fits the absorbance data to obtain the binding constant.
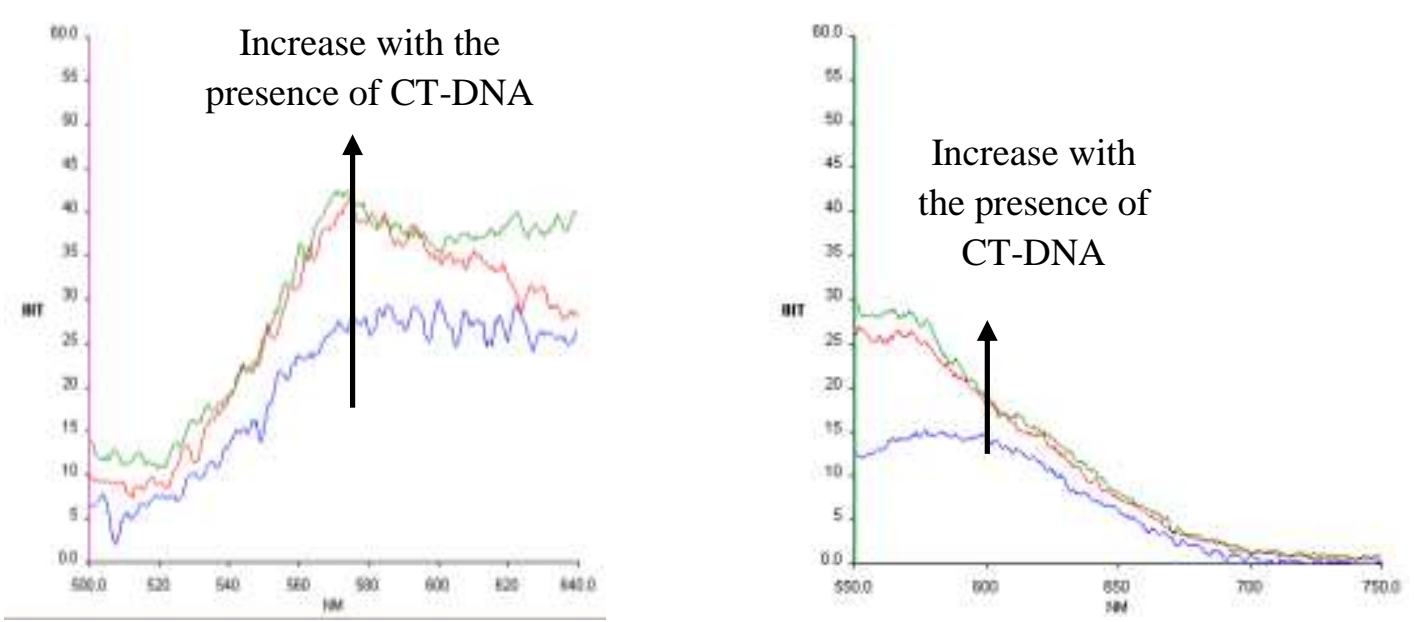

Figure 9. (a) Fluorescence emission spectra of platinum bipyridine complex $(49 \mu \mathrm{M})$ in TRIS.HCl buffer $(\mathrm{pH}=7.4)$ in absence and presence of CT-DNA ( $\lambda$ excitation $=328 \mathrm{~nm}$. $\lambda$ emission $=570 \mathrm{~nm}$ ). (b) Fluorescence emission spectra of platinum bipyridine complex $(49 \mu \mathrm{M})$ in TRIS.HCl buffer $(\mathrm{pH}=7.4)$ in absence and presence of CT-DNA $(\lambda$ excitation $=485 \mathrm{~nm} . \lambda$ emission $=570 \mathrm{~nm})$ 


\section{Emission study}

Platinum (II) complexes with a wide range of aromatic ligand are known to possess luminescent properties. Thus, it was the interest of this study to investigate whether the platinum bipyridine complex in this study is emissive and thus investigate their optical properties changes upon interaction with DNA. Emission titration experiments with 1:1 ratio were performed using constant concentration of complex and CT-DNA $(49 \mu \mathrm{M})$ at different excitation wavelengths. Figure 9 shows the phosphorescence emission spectra in both the absence and presence of DNA in the Tris-HCl buffer. The platinum complex was found to be slightly emissive at $\lambda_{\max }=328$ and $485 \mathrm{~nm}$ respectively. Interestingly, the addition of CT-DNA resulted in an enhancement of phosphorescence emission intensity in both spectra. The emission spectra of the complex showed an increase in the intensity of emission by a factor of 1 indicating the interaction of the complex with DNA. These results confirmed that there was an interaction between phosphorescence platinum(II) bipyridine complex and DNA. These findings will be valuable for the potential use of platinum(II) bipyridine complex as a phosphorescence probe in optical sensor DNA.

\section{Conclusion}

The bis(phenoxy)bipyridine ligand and its platinum complex has been successfully synthesized and characterised. The ${ }^{1} \mathrm{H},{ }^{13} \mathrm{C}$ NMR, IR and mass spectrometry observations were used to elucidate the structure. UV-Vis DNA study showed that platinum complex might be a promising candidate compared to ligand for further applications as a DNA binder and anticancer drugs due to the interaction with CT-DNA via intercalation rather than outside binding. The coordination of ligand with metal centre increases the structural flexibility and thus increases the ability of the complexes to stack and intercalate between the DNA bases. An enhancement of phosphorescence emission intensity upon the interaction with porcine DNA suggests that the platinum complex has the potential as a phosphorescence DNA sensor. These findings will be valuable for the potential use of platinum (II) bipyridine complex as a phosphorescence probe for the detection of porcine DNA in food products.

\section{Acknowledgement}

The authors would like to acknowledge National University of Malaysia for providing the research facilities. This work has been carried out with the support of Malaysian Government through Ministry of Higher Education grant FRGS/1/2013/ST01/UKM/03/2, DIP-2014-016 and 06-01-02-SF0898.

\section{References}

1. Jeffery, J. C., Thornton, P. and Ward, M. D. (1994). An Unusual Chain-like Tetranuclear Manganese (II) Complex Displaying Ferromagnetic Exchange. Journal of Inorganic Chemistry, 33(16): 3612 -3615.

2. Bardwell, D. A., Jeffery, J. C. and Ward, M. D. (1995). Coordination Chemistry of Mixed Pyridine-phenol Ligands - Polynuclear Complexes of 6-(2-hydroxyphenyl)-2,2'-bipyridine with $\mathrm{Ni}(\mathrm{II}), \mathrm{Cd}(\mathrm{II}), \mathrm{Mn}(\mathrm{III})$ and $\mathrm{Mn}(\mathrm{II}) / \mathrm{Mn}(\mathrm{II})$, Journal of the Chemical Society, Dalton Transactions, 3071 - 3080.

3. Maher, J. P., Rieger, P. H., Thornton, P. and Ward, M. D. (1992). Coordination Chemistry of Mixed Pyridine Phenol and Phenanthroline Phenol Ligands, A Variable-Temperature Electron-Paramagnetic Resonance and Magnetic Susceptibility Study on 2 Binuclear Copper(II) Complexes. Journal of the Chemical Society, Dalton Transactions. $3353-3356$.

4. Ramos, J. C. G., Morillo, R. G., Guzman, F. C. and Azuara, L. R. (2013). Metal Based Drug-DNA Interaction, Journal of the Mexican Chemical Society, 57(3): 245 -259.

5. Maryam, H., Mohammadjavad, P., Soheil, Z. M., Pouya, H., Nura, S. G., Maryam, Z., Elham, R., Hamed, K., Chung, Y. L., Hapipah, M. A., Nazia, A. M. and Mahmood., A. A. (2014). A Schiff Base-Derived Copper (II) Complex Is a Potent Inducer of Apoptosis in Colon Cancer Cells by Activating the Intrinsic Pathway. Journal of Scientific World, 2014: 1 - 12.

6. Barton, J. K., Kaiser, J. T. and Song, H. (2012). Crystal Structure of $\Delta$-[Ru(Bpy)2dppz $] 2+$ Bound to Mismatched DNA Reveals Side-By-Side Metalloinsertion and Intercalation, Nature Chemistry, 4: 615 - 620.

7. Zhou, C., Du, X. and Li, H. (2007). Studies of Interactions Among Cobalt(III) Polypyridyl Complexes, 6Mercaptopurine and DNA. Journal of Bioelectrochemistry, 70(2): 446 - 451.

8. Wang, B., Yang, Z. and Li, T. (2006). Synthesis, Characterization, and DNA-Binding Properties of The Ln(III) Complexes With 6-Hydroxy Chromone3-Carbaldehyde-(2'-Hydroxy) Benzoyl Hydrazone. Journal of Bioorganic and Medicinal Chemistry. 14(17): $6012-6021$. 
Norhidayah et al: SYNTHESIS AND CHARACTERIZATION OF 6,6'-BIS(2-HYDROXYPHENYL)-2,2'BIPYRIDYL LIGAND AND ITS PLATINUM COMPLEX FOR THE INTERACTION WITH CT-DNA

9. Zhou, L., Feng, Y., Cheng, J., Sun, N., Zhou, X. and Xiang, H. (2012), Simple, Selective, and Sensitive Colorimetric and Ratiometric Fluorescence/Phosphorescence Probes for Platinum (II) Based on Salen-Type Schiff Bases, Journal of RSC Advances, 2(28): 10529 - 10536.

10. Liu, H. K. and Sadler, P. J. (2011) Metals Complex As DNA Intercalators, Accounts of Chemical Research, 44(5): $349-359$.

11. Kashanian, S., Gholivand, M. B., Ahmadi, F., Taravati, A. and Colagar, A. H. (2007). DNA Interaction With Al-N, N'-Bis(Salicylidene)2,2'-Phenylendiamine Complex, Spectrochimica Acta Part A: Molecular and Biomolecular Spectroscopy, 67(2): $472-478$.

12. Nii, K., Minami, A., Kousuke, W., Igarashi, I. T., Seiji, I. and Toshlhlro, I. (2012), Organic Electroluminescent Devices And Metal Complex Compound, United States Patent US8211553B2.

13. Orejon, A., Castellanos, A., Salagre, P., Castillon, S. and Claver, C. (2005), Oxidative Carbonylation Of Aniline With New Cobalt Catalytic Systems, Canadian Journal Chemistry 83: 764 - 768.

14. Chetana, P. R., Rao, R., Roy, M. and Patra, A. K. (2009), New Ternary Copper (II) Complexes of L-Alanine and Heterocyclic Bases: DNA Binding And Oxidative DNA Cleavage Activity, Inorganica Chimica Acta, 362(13): $4692-4698$.

15. Vilar, R., Arnal, A. A., Buchholz, J. B. and Neidle, S. (2008), Effects of Metal Coordination Geometry on Stabilization of Human Telomeric Quadruplex DNA by Square-Planar and Square-Pyramidal Metal Complexes, Inorganic Chemistry, 47: 11910 - 11919.

16. Huda, N. (2012), Studies Towards Elucidating the Binding Modes between Metal-Salphen Complexes and GQuadruplex DNA, Ph.D. Thesis, Imperial College London.

17. Shahabadi, N., Mohammadi, S. and Alizadeh, R. (2011). DNA Interaction Studies of A New Platinum (II) Complex Containing Different Aromatic Dinitrogen Ligands. Bioinorganic Chemistry and Application, 2011: $1-8$. 